\title{
Islamic Banking and Finance: Shariah Governance in Theory and Practice
}

\author{
Dr M. Mansoor Khan \\ Lecturer in Accounting \\ School of Commerce, University of South Australia, Adelaide, SA 5001 \\ Tel: 61-8-8302-7138Ｅ-mail: mansoor.khan@unisa.edu.au \\ Received: Dec. 27, $2018 \quad$ Accepted: Feb. 11, $2019 \quad$ Published: April 1, 2019 \\ doi:10.5296/jmr.v11i2.14141～URL: https://doi.org/10.5296/jmr.v11i2.14141
}

\begin{abstract}
This paper investigates the case of Shariah governance and compliance at Islamic banks worldwide. It explores fundamental features of Islamic banking policy instruments from Shariah perspectives in order to appraise the business affairs of Islamic banks. This paper finds that Shariah governance has severely failed to ensure religious, ethical and social sanctities of Islamic banks. The personal, consumer finance and deposit-taking operations at Islamic banks are based on interest and time value of money, and a crystal clear case of Shariah violations. The majority of Muslim business and societal groups have shown increasing concerns over the serious Shariah governance and compliance issues at Islamic banks. There are increasing pressures on Islamic banks to prove themselves not only financially viable but also Shariah-compliant and valued-based entities.
\end{abstract}

Keywords: bai salam, distributive justice, equity sharing, ijarah, interest-free finance, mudarabaha, murabaha, musharakah, socio-economic justice, venture capital 


\section{Introduction}

A number of renowned Islamic scholars played a leading role in developing the Islamic banking model in early 1940-50s. These theoretical developments paved the way for launching Islamic banking projects such as Mit-Ghamar Social Bank in Egypt and Tabung Haji in Malaysia in the early 1960s. During the 1970s, a number of major Islamic banks such as Nasser Social Bank Cairo (1971-72), Islamic Development Bank (1975), Dubai Islamic Bank (1975), Kuwait Finance House (1977), Faisal Islamic Bank of Sudan (1977) and Dar Al-Maal Al-Islami (1980) came into being in Middle Eastern countries due to huge socio-political support from their respective governments. In the 980s Pakistan, Iran and Sudan took critical measures to eliminate interest from their economy and banking sector. Western financial institutions such as ABN AMRO, Citibank and HSBC opened Islamic banking windows or subsidiaries to serve Muslim communities.

Islamic banking has spread over Africa, Asia, Europe and North America over the past four decades. There were more than 400 Islamic banking and financial institutions across 75 countries in 2015. Presently, there are nine main Islamic banking hubs which include Bahrain, Qatar, Indonesia, Saudi Arabia, Malaysia, United Arab Emirates, Turkey, Kuwait and Pakistan. These constitute about $93 \%$ of industry assets, with an estimated value of US\$920 billion in 2015 (World Islamic Banking Competitiveness Report 2016; Islamic Financial Services Industry Stability Report 2016; The World Bank's Financial Development Report 2014). Islamic banking has been growing at a faster rate than the conventional banking worldwide over the past years (The Moody's Report 2016on Islamic Banks). Islamic banking soon may become the first choice of the majority of 1.5 billion Muslims across the globe. However, there are growing concerns of Muslim business and community groups which expect that Islamic banks should undertake rigorous $R \& D$ initiatives to develop a wide spectrum of truly efficient and Shariah-compliant products. This paper explores the strategic role of Shariah governance in developing the contemporary theory and practice of Islamic banking worldwide.

This research paper relies on descriptive analytical techniques to examine the published data available in the annual reports and websites of Islamic banks. This paper is composed of six parts. Part 2 provides a brief literature review on Shariah standards and practices in Islamic banking practice. Part 3 explores the primary policy instruments of the Islamic banking model from Shariah perspectives. Part 4 analyses the market-based and Shariah-based features of Islamic banking products and services offered by Islamic banks worldwide. Part 5 explores practical difficulties faced by Islamic banks in operating on Islamic lines. The final part presents summary and conclusion of this paper.

\section{Literature Review}

Islamic banks operate under the constant guidance and surveillance of the Islamic Shariah Board. However, many research studies have registered their serious concerns over the increasing Shariah violations in the Islamic banking industry since its inception. Some Islamic scholars observed that lending practices at Islamic banks are largely based on conventional mechanisms. Islamic banks rely on market interest rates and discounting tables 
to determine return on their financing and investment instruments (El-Diwany, 2006; Haron \& Ahmad, 2000; Kaleem \& Isa, 2003). For example, Islamic banks use LIBOR (London Interbank Offered Rate) to price their murabaha financing and investment contracts (Ahmed, 1987b; El-Askar, 1995; Meenai, 1998; Khan, 2010). They charge higher rate of returns on their long-term financing and loans. They throw all insurance and operating costs upon their customers to ensure almost fixed and risk-free returns on their financing contracts (Bashir, 1999; Abdullah, 2005). They follow the principle: 'pay now, pay less principal'. Islamic banks oblige their clients to buy the promised murabaha goods or compensate them for all damages and losses incurred due to the breach of promise. They recover all fines and additional charges from their customers for late payments and defaults (Khan \& Bhatti, 2008). Islamic banks give almost predetermined and risk-free returns on their saving and terms deposits and investments (Ahmed, 1987b; Kamalzadeh \& Sharjari, 1995; Al-Omar \& Abdel-Haq, 1996; Ashraf, 1998; Warde, 2000; Khan \& Bhatti, 2008; Azmat, Skully \& Brown, 2015).

A number of Islamic banking academics hold that Islamic banks only use interest and LIBOR rates as a benchmark or guide to predetermine the rate of returns on their financing and investment products. Islamic banks may be justified to use the conventional project appraisal techniques to estimate returns or profit on their products as they only use these statistical figures as a guide. Nienhaus (1983) strongly advised that Islamic banks use market interest rates to calculate the profit-sharing ratios. Islamic banks are not only violating Shariah principles but also efficient market rules. They rely on interest rates to value their murabaha investment portfolios but they may not be properly hedged against the interest rate risk by using conventional hedging tools, such as forwards, futures, swaps and options, which are based on gambling and speculations. The Islamic banking theory and practice in Pakistan is the most critical episode of Islamic banking movement worldwide. The Federal Shariah Court Judgement 1991 and Supreme Court Judgement 1999 held that Islamic banking practice in Pakistan was an interest-based activity.

Islamic banks and financial institutions issue Islamic bonds - Sukuks - on the basis of LIBOR. For example, 5-year Al-Musharakaare sukuks issued by Investment Dar Sukuk Company in October 2005 and listed at Bahrain Stock Exchange (BSE) bearing the coupon rate of 6-month LIBOR plus 2 percent per annum. The yield on Qatar Global Sukuks is calculated on the basis of LIBOR on dollar funds plus 0.4 percent p.a. Islamic banking practices have nothing as such to differentiate itself from the conventional banking practice. One of the pioneers of Islamic banking, Qureshi (2005) has described the truth about Islamic banking in the following words, "Islamic banking, as it stands today, is with all due respect and humility, a labelling industry. Everything that is conventional is being labelled and you say it is Islamic."

A recent study empirically investigated the Shariah governance and compliance standards at 63 branches of five full-fledge Islamic banks and five Islamic branches of conventional banks in in Pakistan. It observed that Islamic banks in Pakistan are grossly violating Shariah regarding provision of profit loss sharing investment contracts. These banks could not use truly Shariah compatible profit and loss sharing modes of financing in their operations. 


\section{Mll Macrothink}

Journal of Management Research

ISSN 1941-899X

2019, Vol. 11, No. 2

Furthermore, this study observed very poor performance of Shariah boards at Islamic banks in Pakistan. The customers and communities were largely unsatisfied or indifferent regarding the Shariah-based operations at Islamic banks in Pakistan (Majeed \& Zainab, 2017). Another study observed a significant relationship on gender, age, position and religiosity in influencing the Malaysian Islamic bank employees to commit asset misappropriation. It resolved that Islamic banking leadership should improve their Shariah governance to prevent the frauds and misappropriations in Islamic banks (Fathi, et. el., 2017). A research study noted a dire need of evolving high quality and more consistent Shariah standards and compliance at Islamic banks in Egypt, the Gulf, the UK and the US (Jawadi et. al., 2017). A recent empirical study registered serious Shariah compliance and governance issues at Indonesian Islamic banks. It relied on time series econometric analysis such as Granger Causality and Vector Error Correction Model (VECM) to capture the bi-directional relationship between Islamic banking and interest rate. The study confirmed the historical reliance of Islamic banks on conventional macroeconomic variables, banking tools and interest rate (Nursyansiah, 2018). In sum, a larger part of Islamic banking literature has been registering increasing concerns over the poor Shariah governance and violations in the worldwide Islamic banking practices.

\section{Theory of Islamic Banking Theory - Islamic Banking Model}

Islamic Economics promotes business and finance operations based on equity and risk sharing, mutual funds and venture capital in order to promote wider economic growth, distributive justice and universal brotherhood. The Islamic vision of socio-economic justice is based on abolishing interest, gambling, speculation and other exploitative elements from the human polity. Islamic banking primarily relies on risk-sharing or profit and loss sharing instruments of mudarabah and musharakah to perform the intermediation role between savers (depositors) and borrowers (investors). It also applies murabaha, Ijarah, bai salam and bai istisna as secondary interest-free instruments to conduct its business and investment operations. It offers qard-e-hasanah or free of cost loans (goodly loans) to the needy and poor people.

\subsection{Mudarabah (Joint Venture) - Profit and Loss Sharing (PLS) Modes}

In mudarabah, one party (fund provider or $r a b-u$-mal) contributes financial capital and the other party (fund manager or mudarib) contributes human capital to undertake a business venture for sharing profit or loss. Both parties share the profit on agreed terms, however, the fund provider bears a financial loss and the fund manager bears a managerial loss by not receiving any rewards for his/her efforts and time spent in managing a mudarabah business (Saleh, 1986; Khan \& Bhatti, 2008).

Under the mudarabah banking model, the Islamic bank accepts funds from depositors and extends them to borrowers on a risk-sharing basis. The Islamic bank also directly invests deposits in profitable business ventures. The bank may assume an active or passive role in managing the mudarabah business affairs. The bank may apply systematic methods to determine the growth or erosion (profit or loss) in mudarbah investments for the given period (Baldwin \& Wilson, 1988; Al-Amin, 1990; Bacha, 1995). 


\subsection{Musharakah (Partnership) - Profit and Loss Sharing (PLS) Modes}

In musharakah, two or more persons pool their financial and human resources to undertake a business venture for sharing profit or loss. The partners enjoy equal rights to manage the musharakah business. However, one or more partners can manage the musharakh business on behalf of other partners under the principle of agency. The Islamic bank relies on the musharakah model to accept deposits and extend them to entrepreneurs and borrowers to undertake joint business activities. The Islamic bank combines its own equity or finance with deposits to undertake musharakah investments (Nienhaus, 1983; Khan \& Mirakhor, 1987; Hussain, 1993).

Islamic banking should heavily rely on mudarabah and musharakah modes to achieve Islamic socio-economic aims and objectives. Islamic banks should perform the actual role of businessman, partners and traders in the marketplace under these risk-sharing arrangements. The rate of return on PLS investments should be based on their productivity and outcomes.

\subsection{Murabaha (Deferred Payment Sale)}

Under a murabaha arrangement, the Islamic bank buys goods from the manufacturer and sells them to the client on an instalment basis at a price that covers their cost and mark-up. The primary sources of Islamic Shariah do not approve the murabaha mode of financing. The holy Prophet Mohammad (pbuh) disapproved the case of charging different prices for credit and cash sales of any article or commodity. Sammak reported that the holy Prophet Mohammad (pbuh) said that whoever makes two sales in one transaction will end up either with the lesser of the two sales or riba (interest) (Saadullah, 1994). Any increase in the price of credit sale is interest which is rewarded to the seller or lender for the deferment. However, early Islamic jurists such as Imam Malik (796) and Imam Shafi (820) approved murabaha sales and later on Sarakhsi (1091) and Marghinani (1197) permitted higher price of murabaha sale as a normal practice in trade (Saadullah, 1994; Vogel and Hayes, 1998). Given the strong resemblance of murabaha with interest-based activity, the majority of Islamic scholars strongly advised to use it only in exceptional cases (Siddiqi, 1993; Ahmed, 1987b; Khan, 1995).

Islamic banks should strictly follow Shariah principles and governance to ensure truly Islamic and trade-based nature of murabaha financing in their operations. They should deal in economic assets or goods as traders, businessmen or suppliers to enter into a genuine sale contracts with their customers. Islamic banks should bear all market risks and losses arising from the customer's refusal to buy the promised murabaha goods. Islamic Shariah does not permit Islamic banks to change the agreed price of murabaha contract or charge any additional amount from the customer for any delay or default in payment after concluding the the muarbaha contract. Islamic banks cannot enter into a murabaha contract under a buy-back agreement because such arrangements provide a full cover to perform interest-based operations by meeting its trade-related requirements on papers only. They should perform the real role of a financer or lender in murabahah dealings (The FSC Judgement of Pakistan 1992; The SC Judgement of Pakistan 1999). 


\subsection{Ijarah (Lease) Financing}

In ijarah or lease financing, the owner or lessor of an economic asset allows the lessee to extract its benefits in return of lease or rental payments over a contractual period. Islamic banks use lease financing to meet the commercial and personal needs of their customers. Islamic Shariah strongly supports the operating lease wherein the lessor holds the ownership of the leased asset and thereby bears all costs and risks associated with its operations, repairs, insurance and depreciation, etc. Islamic banks should not enter into any binding promise or agreement of sale of the leased asset with the lessee until the expiry of lease contract. They should sell the leased asset on its fair market value to the lessee or any other party after the end of the lease contract. They should bear all operating and maintenance costs of the leased asset. The instalment payment should be based on the actual productivity of leased asset otherwise this equity-based instrument might turn into a debt instrument (Siddiqi, 1993; Warde, 2000; Khan \& Bhatti, 2008).

\subsection{Bai Salam or Bai Istisna (Advance Payment or Procurement Engagement)}

In bai salam or bai istisna, the Islamic bank grants an advance payment to the client against the farm or manufactured goods. The client delivers the promised goods to the Islamic bank on a future date who sells them for a profit. These financing modes have been widely practised to meet the short-term financial needs of the agricultural and other sectors in Islamic economy. Islamic Shariah envisages a real role of an Islamic bank as a trader of goods under bai salam or bai istisna dealings. It obliges the Islamic bank to sell the bai salam or bai istisna's goods after obtaining their actual possession and title. It urges the Islamic bank to determine the price of bai salam or bai istisna contracts under fair and efficient market principles (Khan and Mirakhor, 1987; Siddiqi, 1993; Khan \& Bhatti, 2008).

\section{Islamic Banking Practice Worldwide}

Islamic banks largely rely on ijarah, murabaha and diminishing musharakah modes of financing to meet the personal needs of their customers. They accept deposits under mudarabah and musharakah principles. This section explores the salient features of personal and consumer finance, and the deposit-taking operations at worldwide major Islamic banks.

\subsection{Ijarah/Lease House Financing}

A large number of Islamic banks use ijarah muntahiyya bittamlik (lease to own) for home financing. This mode combines the lease and sale contracts into one, which is very similar to lease financing. Islamic banks purchase the prescribed house from the original seller and then enter into lease and sales agreements with the customer. They promise to gift the house or sell it at a nominal price to the customer after receiving the full lease payments. They allow the customer for an early settlement of lease and sale contracts by making the full payment of outstanding lease amount. They make their customers liable to bearing all costs and risks of lease contracts such as the costs of survey and land registration, evaluation fees, life and property insurance fees, maintenance, rates and damages of the leased property. They charge their customer for late payments. If the customer fails to pay the outstanding/agreed lease payments, Islamic banks take legal possession of the leased house and sell it to recover their 
funds. Islamic banks extend lease funds for house construction and charge the profit accrued during the construction period as an advance rental. They offer finance/refinance facilitates to buy and settle the existing house loans of their customer with other financial institutions (Warde, 2000; Khan \& Bhatti, 2008).

The majority of Islamic banks provide a 'real estate calculator' to work out the total cost/value and monthly payments to borrow the given amount of the real estate loan. For example, Al Rajhi Bank offers house financing of SR888,451 at 2.95\% term or finance cost and 5.05\% effective rate over 20 years (Al Rajhi Bank, 2018). Dubai Islamic Bank offers house financing for 25 years at the cost of $3.99 \%$ p.a, based on EIBOR (DIB, 2018). Kuwait Finance House offers real estate financing of BD 100,000, at profit rate of $7.28 \%$ p. a., with monthly instalments of BD688.46 over 25 years (KFH, 2018). Islamic banks require their customers to provide a life insurance policy to finance over a certain limit. For example, KFH requires from its customers to buy a life insurance policy for house financing over and above BD150,000 (KFH, 2018). Islamic banks earn almost guaranteed and predetermined rate of return on their house finance products.

The Shariah validity of merging a lease contract and sale contract into a single deed is highly questionable. Islamic banks cannot merge lease and sale contacts into one contract otherwise they will end up with interest-based dealings. They cannot enter into a sale agreement to give away the underlying house or economic asset as a gift or sell it at very negligible value to customers after the end of a lease contract because it constitutes a sheer violation of Islamic Shariah as well as fair and efficient market principles. Islamic banks should undertake a genuine sale activity and thereby sell the leased house at a fair market price to the lessee or any interested party after the end of a lease contract. The Supreme Court Judgement of Pakistan 1999 observed that the lessor could only sell the leased asset to the lessee after the end of a lease contract (Khan \& Bhatti, 2008).

Islamic banks cannot buy or refinance the existing house loans or debt of their customers with other financial institutions. The so-called Islamic lease or murabaha contacts hold a trade-based nature and once they are converted into a monetary debt, they cannot be bought or sold by Islamic banks because it will amount to selling or buying money for money on an interest basis. It is the fundamental difference between the Islamic bank and the conventional bank that the former acts as trader or businessman and the latter acts as money broker or dealer on the basis of interest.

Under a valid Islamic lease contract, Islamic banks (as lessors) should bear all costs and risks associated with the useful life, rate of return on investment, operating and maintenance costs, losses and other liabilities arising from the use of leased property. Islamic banking customers are not the real owners of property and thereby they should not bear any risks and costs associated with the leased property. Therefore, Islamic banks cannot make it legally binding upon their customers to pay for any losses, liabilities, costs, claims, actions, damages, expenses in relation to the leased property. They cannot charge rent during the house construction period because customers do not derive any economic benefits during that period. If customers bear all operating risks and costs then it is meant to be a sale contract 
wherein the given house or asset has two different values - the spot or present value and the future value. The difference between both values is the predetermined return or interest earned by Islamic banks. In 999, after consulting with all contemporary Islamic banking scholars and practitioners, the Supreme Court of Pakistan ordained that the contemporary financial lease practice in the Islamic banking and finance world is an interest-based activity and it must be banned with an immediate effect (The SC Judgement of Pakistan 1999).

\subsection{Murabaha House Financing}

A number of Islamic banks use murabaha mode for house financing. Under this arrangement, Islamic banks purchase the prescribed house and sell it to the customer by adding an agreed mark-up on a deferred payment basis. Islamic banks express a house finance contract as a fixed annual percentage of the outstanding amount of house finance. Some Islamic banks use the annual percentage rate (APR) to discount the future payments of their real estate contracts. For example, Bank Islam Malaysia offers house financing for a residential property/house from RM100,000-500,0000 up to 35 years, under the property financing - tawarruq - baiti home finance scheme. The bank purchases the prescribed property and adds an agreed mark-up or profit by using the fixed ceiling profit rate (CPR). The bank demands the customer to submit collateral or guarantor against the leased finance in some cases. The bank's base rate covers the cost of funds based on 3-month KLIBOR as the reference rate plus a funding cost adjustment. The bank forfeits the property if the customer fails to make the required payments. The bank offers rebates to the customer on the early settlement of house finance (Bank Islam Malaysia, 2018).

Islamic banks use murabaha house financing wherein the given house or economic asset holds two prices at the same time. The underlying house has the spot or current market price which Islamic banks pay to purchase it. It also bears the present price or value of deferred payments paid by the customer over the contractual period. The difference between the present and future price of the given economic asset is regarded as an interest by Islamic Shariah. Islamic banks are indulged in selling money for money at the predetermined rate of return by using the house as a proxy to cover their interest-based lending and investments. It is un-Islamic for Islamic banks to charge higher or additional mark-up from customers to cover the risk of delay or default in the repayment of the murabaha loan.

The instalment payments on their murabaha or lease contracts are based on fixed or floating interest rates. Islamic banks determine the price of their home finance products based on conventional market key factors such as 'cost of debt/finance', 'interest rate' 'demand and supply of loans in financial markets', 'operating/managing costs', etc. Western financial institutions are money dealers and brokers and Islamic banks are traders, businessmen and so both are a world apart. Islamic banks cannot use conventional money dealers' tools such as interest rate, discounting table as a guide or benchmark to conduct their affairs as traders and businessmen under Islamic economic principles. However, Islamic banks have not developed their own Islamic or independent mechanisms to determine the price of their lease or murabaha contracts. Islamic banks use houses as a proxy to earn almost risk-free and predetermined return on their house financing contracts. In conventional house financing 
contracts, customers and borrowers enjoy more flexibility and freedom in terms of ownership, possession and utilization of their property to suit their needs. However, the terms and conditions of Islamic house financing are harsher than conventional banking contracts. Islamic products are more costly and less competitive because Islamic banks need to recover the costs of dressing up these interest-based products into Islamic ones.

Islamic banks transfer huge insurance costs on their customers to cover all sorts of risks associated with their house financing operations. They seek compensation from their customers for any unpaid insurance claims, and for losses and damages arising from misuse or negligence. Islamic banks sell the murabaha and leased property to recover their losses arising from the customer's breach or default. The insurance features attached to Islamic house financing bear interest, gambling, speculation and elements of uncertainty which are absolutely banned by Islamic Shariah. It is unlawful for Islamic banks to recover losses from their customers who refuse to purchase the promised murabaha goods. Islamic banks cannot recover fines and additional charges from their customers for late payments on leased or murabaha debt because it will amount to interest. The rebate for early payments of borrowed funds confirming that Islamic banks house finance products are based on interest and time value of money mechanisms. The Islamic banks' asset and investment portfolios are hugely concentrated in murabaha and lease modes of financing. The FSC Judgement of Pakistan 1991 and SC Judgement of Pakistan 1999 declared that Islamic banks use murabaha financing is purely an interest-based instrument (The FSC Judgement of Pakistan 1992; The SC Judgement of Pakistan 1999).

\subsection{Musharakah Home Financing}

Islamic banks offer house financing under diminishing musharakah partnership. For example, Meezan Bank of Pakistan enters into a joint ownership of property with the customer and contributes up to $75 \%$ of property value in the joint partnership. The customer makes monthly payments to the bank which covers the rental value and equity share to buy the bank's share of investment in the house. The underlying payments gradually diminish the bank's equity share in the house and increase the customer's equity share. The customer becomes the full owner of the house upon making the final payment to the bank. Meezan Bank offers finance for a maximum of 25 years for buying or building (up to Rs 50 million) or renovating (up to Rs. 10 million) a house. Islamic banks buy the existing house finance contracts of their customers with other financial institutions (Meezan Bank, 2018). The majority of Islamic banks rely on interest-rates and discounting tables to ensure predetermined and risk-free returns on their musharakah house financing contracts.

\subsection{Auto Finance}

Islamic banks purchase the car and rent it out to the customer for an agreed period ranging from 1-7 years. Islamic banks gift or sell the car to the customer at a token amount after the lease period. The customer simultaneously enters into two agreements, asset purchase agreement (undertaking) and service agency or lease agreement. The customer bears all costs of repair, maintenance and replacements during the lease period. Meezan Bank also offers the residual value ijarah for up to 7 years. Under residual or operating ijarah, the customer 
pays the agreed instalment payments over the lease period. After the completion of lease period, the customer has the option to either purchase the car at the agreed selling price or return it to the bank (Meezan Bank, 2018). Al Barakah Bank requires its customers to make the agreed lease payments to obtain full ownership of the car. Dubai Islamic Bank offers auto financing under asset ijarah financing facility - ijarah muntahia bittamleek - at competitive profit rate of $1.99 \%$ p.a over the 5-year period (DIB, 2018). Kuwait Finance House charges $6.75 \%$ p.a on its auto lease finance for 7-years (KFH, 2018). Ajman Bank offers 5-years car finance up to AED 400,000 (Ajman Bank, 2018).

Islamic banks largely rely on murabaha for car or auto financing. They purchase the car from the original owner and add the agreed mark-up to sell it at the price payable by the customer in a number of instalments. For example, Al Barakah Bank provides taqseet finance, based on murabaha to customers for buying a car or other household goods at a fixed and predetermined rate of return. Bank Islam Malaysia offers car financing for 9 years on the basis of murabaha. The bank offers early settlement rebate and recovers $1 \%$ late payment charges on the overdue amount from customers. The bank uses the Islamic interbank money market rate to determine the price and rate of return on its car financing products.

Islamic banks such as Al Barakah Bank and others use the diminishing musharakah mode for car financing. The Islamic bank's share decreases gradually as a result of a gradual sale of its shares to the customer against the payment of instalments. The bank makes profit by selling its share to the customer at higher price than its original value. Islamic banks recover all costs and damages for the breach or termination of car finance contract from their customers. They bind the customer to purchasing the car at the end of the leasing period. Islamic banks (such as Qater Islamic Bank) trade in the customer's old car for a new one. Islamic Shariah holds that a trade in or exchange of two commodities of same genus constitutes a hidden form of interest - riba al-fadl. Islamic banks should undertake two independent sales transactions of an old or new car to comply with underlying Islamic teachings (Khan \& Bhatti, 2008).

Islamic banks demand personal or collateral security from the customer on car financing. They take a signed declaration from the customer which authorizes them to sell the car to recover any outstanding or unpaid instalments. If the sale proceeds are not sufficient to cover the outstanding amount then the customer is personally liable to satisfy the accrued claims. Islamic banks also holds customers responsible to satisfy them against all claims, demands, losses, expenses (including legal fees) penalties, actions, suits, damages and liabilities caused by their misuse or negligence.

Islamic banks use conventional discounting tables and interest calculators to calculate the value and rate of return on their car finance products. They include risk premium factors such as 'monthly salary', 'existing loan commitments', and 'salary transfer or bank account of customers at lending bank' which are used to calculate the price and rate of return on their car financing products. For example Al Rajhi Bank has given a 'car instalments calculator' on its website, which is based on the followings factors: price of car (borrowed finance) $\mathrm{x}$ down payment and finance period. The bank offers short-term car loans with or without a salary transfer from 5.2.4 - 7.4\% p.a. The interest rates are lower if the borrower's monthly salary is 
transferred to Al Rajhi Bank, vice versa (Al Rajhi Bank, 2018). Islamic banks follow opportunity costs and time value of money concepts in their car financing products. Islamic banks (such as Qatar International Islamic Bank) buys out the existing car finance contracts or liabilities of the customer with other financial institutions which is against Islamic Shariah as well as their own basic operational modalities (QIIB, 2018).

\subsection{Consumer and Personal Finance}

Islamic banks provide consumer finance under the murabaha principle for household items such as air conditioners, refrigerators, televisions, furniture, house renovations, etc. For example, Meezan Bank extends consumer financing from Rs. 35,000 - 1,000,000 with 15\% down payment within a 24-month period (Meezan Bank, 2018). Ajman Bank offers consumer financing under murabaha up to AED 3,000,000 for all household and electronic goods (Ajman Bank, 2018). Bank Islam Malaysia uses murabaha financing to meet the working capital needs of businessmen for palm oil, plastic resin, rubber, cocoa beans, timber, etc (Bank Islam Malaysia, 2018). Islamic banks offer personal financing for 1-5 years at a fixed rate under murabaha and lease arrangements for education and training, medical care, marriage, family tourism, debts and other personal needs of customers. For example, Al Rajhi Bank buys shares and sells them to the customer at a profit on a deferred basis. The customer sells back these shares to the bank to receive money needed for meeting their personal needs (Al Rajhi Bank, 2018). Bahrain Islamic Bank offers Tas'heel finance based on the murabaha model up to BD 100,000 for 7 years to meet the personal needs of customers. Ajman Bank meets customer financing needs for tourism and travel through service ijarah. The bank buys the prescribed services and allows the customer to utilize them in return of the rental payments over the agreed period (Ajman Bank, 2018). In the early years, Islamic banking scholars had observed that Islamic banks could not develop proper financing instruments to meet consumer needs. With the passage of time, however, Islamic banks have been increasingly relying on fictitious trade-based activities for financing the personal needs of consumers. The FSC Judgement of Pakistan 1991 and SC Judgement of Pakistan 1999 declared that murabaha financing for meeting the underlying personal needs of customers is an interest-based activity (The FSC Judgement of Pakistan 1992; The SC Judgement of Pakistan 1999).

\section{6 Deposits}

Islamic banks collect funds from their depositors through interest-free current accounts, saving accounts and term deposit accounts. They consider current accounts as goodly loans and thereby share no profit or loss with these depositors. Islamic banks accept saving and fixed-term deposits under mudarabah arrangements. They use these funds to invest in profitable investments (general mudarabah). They share the resulting profits from mudarabah investments with their depositors on agreed profit sharing ratios. Generally Islamic banks calculate profit on a daily or weekly basis and pay it on a monthly or quarterly basis. They do not impose any restrictions on number of withdrawals and maintaining a minimum balance in saving accounts.

Islamic banks calculate the rate of returns on saving and term deposits based on the amount 
and time period of investment. For example Meezan Bank offers 3-month, 1-year, 3-year and 5 -year term deposits at the rate of return of $1.09 \%, 1.34 \%, 1.44 \%$ and $1.54 \%$ p.a. respectively. The bank offers a 'certificate of Islamic investment' for 3-5-years at a rate of return of $3.9 \%$ - 5.60\% p.a. It also offers term deposit investment schemes that include Meezan Amdan Certificate' from 5 - 7 years with profit ranging from $5.67 \%$ to 5.99 p.a. and Meezan Amdan 6 months-7 years with rate of return of 5.65\% to 5.99\% p.a (Meezan Bank, 2018). Ajman Bank offers 'wakala term deposits' with a minimum deposit of AED 100,000 and distribute the predetermined and guaranteed returns on its saving and term deposits (Ajman Bank, 2018). Bahrain Islamic Bank offers a half-yearly pre-determined and guaranteed return on its deposits based on monthly average balances (Bahrain Islamic Bank, 2018). Dubai Islamic Bank distributes profit at the rate of $1.06 \%-1.66 \%$ p.a. on its $1-12$ months saving accounts (DIB, 2018). Bank Islam Malaysia offers term deposit (tawarruq) from 1-60 months with a guaranteed capital and rate of return to their customers. The Bank penalizes depositors for pre-mature withdrawals. For example, if a term deposit completed $3 / 4$ months then the bank will deduct $50 \%$ of the agreed profit from customers in addition to charging any brokage fees, etc (Bank Islam Malaysia, 2018).

Al Barakah Bank distributes the predetermined rate of return on its saving accounts on a monthly basis. It offers term deposits - mudaraba investment accounts - for 1month -12 months, which are fully protected for the capital and rate of return. The Bank offers term

deposits for $1-24$ months with predetermined profit ranging from $0.50 \%$ to $1.001 \%$ p.a. ( $\mathrm{Al}$ Barakah Bank, 2018). Faisal Islamic Bank of Egypt allows the predetermined profit of 1.75\% on its investment accounts and 3.50\% on its saving certificates (Faisal Islamic Bank, 2018). A number of Islamic banks offer the mudarba certificate of Islamic Investment for 3 months to 5 years to distribute the predetermined periodic return to investors. In the given context, Islamic banks fully ensure predetermined and guaranteed returns on their saving and term deposits just like their conventional counterparts.

\section{Practical Difficulties in the True Islamic Shariah Compliance at Islamic Banks}

The Islamic banking model envisages Islamic banks as trade-based entities. However Islamic banks perform a full-fledged conventional-based financial intermediary role by acting as businessmen, partners and traders on the papers only. There are a handful of competent Shariah experts holding lucrative positions at top Islamic banks and financial institutions. They do not take a genuine interest in nurturing a crop of truly competent Shariah experts to work in the Islamic banking worldwide. Islamic Shariah experts at small Islamic banks largely approve seriously dubious instruments due to their limited expertise about the very nature and complexities of international financial markets. Islamic Shariah scholars have seriously failing to promote universal standards of Islamic banking theory and practice worldwide. Islamic banks have many and varied names, methods and documents for recording and reporting any given Islamic transaction. Also, Islamic rating agencies have failed to improve the Shariah-compliance standards at Islamic banks. There is a serious dilemma of credibility, transparency, disclosure and reporting in the Islamic banking industry across the globe (Haniffa \& Hudaib, 2007; Hassan, et. el., 2010; Khan, 2013). 


\section{Mll Macrothink}

Journal of Management Research

ISSN 1941-899X

2019, Vol. 11, No. 2

Islamic Shariah scholars have grossly failed to promote R\&D to develop truly distinctive, innovative and competitive products and services for Islamic banking customers. Islamic banks experience a serious dearth of medium and long-term investment instruments and venues. Islamic money and capital markets are too nascent and cannot resolve the chronic mis-match of assets and liabilities and liquidity problems at Islamic banks. Islamic banking leadership has largely failed to work in collaboration with Shariah scholars to develop truly Islamic and competitive products and services in the contemporary world of business and finance (Khan \& Mirakhor, 1987; Khan, 1995; Khan \& Bhatti, 2008; Khan, 2013; Azmat, Skully \& Brown, 2015). The majority of Islamic banking leadership and staff come from the conventional banking world and they have a little interest and expertise to run their business affairs in full compliance with Islamic Shariah. Consequently, Islamic banks largely follow conventional banking infrastructures, products and services to run their business affairs (Ahmed, 1994; Warde, 2000; Azmat, Skully \& Brown, 2015). The poor quality of Shariah governance significantly harm the cause of Islamic banking among Muslim businesses, communities and market players.

Islamic banks cannot afford to distribute risk-sharing returns on their deposits due to the absence of the depositors' insurance and effective regulations. They cannot use PLS modes of financing and investments due to inefficient tax and regulatory systems and poor standards of morality, literacy and socio-economic support in majority of Muslim countries (Chapra, 1985; 2001; Siddiqi, 2000; Khan, 2013; Azmat, Skully \& Brown, 2015). Islamic banks working under conventional regulatory market environment find it difficult to compete with their conventional counterparts. There is a lack of community and stakeholder consultation, engagement and representation at Islamic banking discipline. Islamic banks are highly reluctant to provide any information to academics and researchers to support research and innovation in Islamic banking. There are growing concerns in Muslim communities over the poor financial and Shariah standards and practices at Islamic banks.

\section{Summary and Conclusion}

Islamic banking substitutes the interest-based financial intermediation with a risk-sharing and interest-free intermediation. It was largely expected by market players that Islamic banks will add more efficiency, venture capital, ethical and competitive and diversified features in the business and finance world. However, they have seriously disappointed Muslim businesses and communities by blindly following the same conventional banking practices under the auspicious of their Islamic Shariah boards. Islamic banks almost ensure guaranteed and fixed returns on their lending and borrowing products and services. The Islamic banking leadership and staff have no true belief and expertise to eliminate interest from their business affairs. They have failed to take truly rigorous R\&D to develop their own tools, systems and a wide spectrum of truly efficient and Shariah-compliant products for Muslim clientele and other market players.

Islamic banking leadership and Shariah governance are primarily responsible for gross Shariah violations at Islamic banks. They have failed to evolve universal accounting, regulatory and Shariah standards to ensure greater uniformity, accountability and 
responsibility of worldwide Islamic banking practices. They have not shown a genuine interest in developing their own dynamic leadership and workforce with Shariah-cum-technical knowledge and skills. Islamic banking depositors and customers are too risk-averse to lend or borrow money under the PLS arrangements. The majority of Muslim society and market players hold gross misgivings and doubts about the originality of worldwide Islamic banking practices. Islamic banks face the biggest challenge of establishing their religious and ethical legitimacy among Muslim businesses and communities. There is a pressing demand on Islamic banks to develop genuinely Islamic and innovative products and services to remain competitive and ethical entities in the global business and finance.

\section{References}

Abdullah, D. (2005). Shariah compliance review, Islamic Finance news, 2(9), 9.

Ahmed, Z. (1987a). Islamic banking on the crossroads, in Jean-Francois Sezec (Eds.),The Financial Markets of the Arabian Gulf, pp. 22-30.

Ahmed, Z. (1987b). Islamic banking on the crossroads, Economic Outlook, 18(10), 9-18.

Ahmed, Z. (1994). Islamic banking: state of the art. Islamic Economic Studies, 2(1), 1-34.

Ajman Bank. (2018). Available: http://www.ajmanbank.com. (December 23, 2018).

Al Baraka Islamic Bank. (2018). Available: http://www.barakaonline.com. (November 27, 2018).

Al Rajhi Bank. (2018). Available: http://www.alrajhibank.com.sa. (July 13, 2018).

Al-Amin, H A. (1990). Mudarabah a shariah we tat-biqatuha al-haditha, Jeddah: IRTI, IDB.

Al-Omar, F., \& Abdel-Haq, M. (1996). Islamic banking: theory and practice and challenges. New Jersey: Oxford University Press.

Ashraf, S. M. (1998). Impediments in the Islamization of banks and financial Institutions. New Horizon, 82(2), 3-5.

Azmat, S., Skully, M., \& Brown, K. (2015). Can Islamic banking ever become Islamic? Pacific-Basin Finance Journal, 34(1). 253-272. https://doi.org/10.1016/j.pacfin.2015.03.001

Bacha, O. I. (1995). Conventional versus mudarabah financing: An agency cost perspective. Journal of Islamic Economics, pp. 24-36.

Bahrain Islamic Bank. (2018). Available: http://www.bisb.com. (June 10, 2018).

Baldwin, D. (1990). Turkey: Islamic banking in secularist context, in Rodney Wilson (Eds.), Islamic Financial Markets, London: Routledge Publications.

Bank Islam Malaysia Berhad. (2018). Available: http://www.bankislam.com. (September 30, 2018).

Bashir, M. (1999). Risk and profitability measures in Islamic banks: the case study of two Sudanese banks. Islamic Economic Studies, 6(2), 1-26. 
Chapra, M. U. (1985). Towards a just monetary system, Leicester: The Islamic Foundation.

Chapra, M. U. (2001). Islamic banking and finance: the dream and reality. Journal of Banking and Finance, 18(2), 7-39.

Dubai Islamic Bank (2018). Available: http://www.dib.ae.(January 30, 2019).

El-Ashkerr A. (1995). Profit index as a substitute of LIBOR in Islamic banking operations. Jeddah: Islamic Research and Training Institute (IRTI).

EL-Diwany, T. (2006). Islam today: Is Islamic banking Islamic?, Interactiveislam.com, Available:

$<t t p: / / w w w . i n t e r a c t i v e i s l a m . c o m / h t m l / m o d u l e s . p h p ?$ name $=$ News \&file $=$ article $\&$ sid $=199>(\mathrm{D}$ ecember 19, 2018).

Faisal Islamic Bank of Egypt. (2018). Available: http://www.faisalbank.com.eg. (August 26, 2018).

Fathi, W. N. I. W. M., et. el. (2017). Potential employee fraud scape in Islamic banks: the fraud triangle perspective, GJAT, 7(2), 79-92.

Gulf Finance House (2018). Available: http://www.gfh.com. (November 12, 2018).

Haniffa, R. M., \& Hudaib, M. (2007). Exploring the ethical identity of Islamic banks via communication in annual reports. Journal of Business Ethics, 76(1), 97-116. https://doi.org/10.1007/s10551-006-9272-5

Haron, S., \& Ahmad, N. (2000). The effect of conventional interest rate and rate of profit on funds deposited with Islamic banking system in Malaysia. International Journal of Islamic Services, 1(4), 1-9.

Hassan, M. K., et. al. (2010). Ethical gaps and market value in the Islamic banks of Bangladesh. Review of Islamic Economics, 14(1), 49-75.

Hussain, T. (1993). Greater reliance of PLS, Journal of Islamic Banking and Finance, 11-19.

Islamic Bank Malaysia. (2018). Available: http://www.bisb.com. (January 25, 2019).

Islamic Financial Services Board. (2016). Islamic Financial Services Industry Stability Report 2016. Available: http://www.ifsb.org (February 19, 2018).

Jawadi, F., et. el. (2017). Does Islamic banking performance vary across regions? A new puzzle, Applied Economics Letters, 28(8), 567-570. https://doi.org/10.1080/13504851.2016.1210764

Kaleem, A., \& Isa, M. (2003). Causal relationship between Islamic and conventional banking instruments in Malaysia. International Journal of Financial Services, 4(4), 1-12

Kamalzadeh, M., \& Sharjari, H. (1995). The interest rate and Islamic banking. Islamic Economic Studies, 115-122.

Khan, F. (2010). How 'Islamic' is Islamic Banking? Journal of Economic Behavior and 
Organization, 76(1), 805-820. https://doi.org/10.1016/j.jebo.2010.09.015

Khan, M. M., \& Bhatti, M. I. (2008). Developments in interest-free banking, UK: Palgrave Macmillan. https://doi.org/10.1057/9780230582309

Khan, M. M. (2013). Developing a conceptual framework to appraise the corporate social responsibility performance of Islamic banking and finance institutions. Accounting and the Public Interest, 13(1), 191-207. https://doi.org/10.2308/apin-10375

Khan, S. K., \& Mirakhor, A. (1987). Theoretical studies in Islamic banking and finance, Houston: Book Distribution Centre.

Khan, T. (1995). Demand for and supply of mark-up and PLS funds in Islamic banking: some alternative explanations. Islamic Economic Studies, 39-78.

Kuwait Finance House .(2018). Available: http://www.kfh.com. (May 20, 2018).

Majeed, M. T., \& Abida Z. (2017). How Islamic is Islamic banking in Pakistan? International Journal of Islamic and Middle Eastern Finance and Management; 10(4), 470-483. https://doi.org/10.1108/IMEFM-03-2017-0083

Meenai, A. A. (1998). Islamic banking - where are we going wrong? New Horizon, 72(1), 3-5.

Meezan Bank of Pakistan. (2018). Available: http://www.meezanbank.com (May 29, 2018).

Moody's Investors Service. (2016). Islamic finance; prospects remain strong despite subdued sukuk issuance, Available: https://www.moodys.com. (March 31, 2018).

Nienhaus, V. (1983). Profitability of Islamic PLS banks competing with interest banks: problems and prospects. Journal of Research in Islamic Economics, 1(1), 37-47.

Nursyansiah, T. (2018). Macroeconomic Determinants of Islamic Banking Financing, Islamic Finance and Business Review, 11(2), Available: https://doaj.org/article/1e4e18f9d310442aaf250695354579d2. (January 21, 2019).

Qatar International Islamic Bank (2018). Available: http://www.qiib.com.qa. (May 17, 2018).

Qureshi, D. M. (2005). Vision table: questions and answers session, in Proceedings of the First Pakistan Islamic Banking and Money Market Conference, 14-15 September, Karachi, pp. $15-22$.

Saleh, N. (1992). Unlawful gain and legitimate profit in Islamic alw: riba, gharar, and Islamic banking. ( $2^{\text {nd }}$ edition,), London: Graham and Trotman.

Siddiqi, M. N. (1993). Banking without interest, Leicester UK: The Islamic Foundation.

Siddiqi, M. N. (2000). Islamic finance and beyond: premises and promises of Islamic economics. Conference proceedings of the Third Harvard University Forum on Islamic Finance, Mass: Harvard University, Cambridge.

Siddiqui, S. H. (1994). Islamic banking. Karachi: Royal Book Company. 


\section{Macrothink}

Journal of Management Research

ISSN 1941-899X 2019, Vol. 11, No. 2

The Federal Shariat Court Judgement of Pakistan. (1991). Islamic Shariat Court, Islamabad, Pakistan.

The Supreme Court Judgment of Pakistan. (1999). Pakistan Supreme Court, Islamabad, Pakistan.

The World Bank. (2014). The World Bank's Financial Development Report 2014: Financial Inclusion. Available: https://openknowledge.worldbank.org/bitstream/ handle/10986/ 16238/9780821399859.pdf? sequence=4. (July 29, 2018).

Vogel, F. E., \& Hayes, S. L. (1998). Islamic Law and finance, religion, risk and return. London: Kluwer Law International, London.

Warde, I. (2000). Islamic finance in the global economy. ( $1^{\text {st }}$ ed.), Edinburg: Edinburgh University Press. https://doi.org/10.3366/edinburgh/9780748612161.001.0001

World Islamic Competitive Report (2016). Available: http://reports.weforum.org/global-competitiveness-report-2015-2016/ (October 14, 2018).

\section{Copyright Disclaimer}

Copyright for this article is retained by the author (Dr M. Mansoor Khan), with first publication rights granted to the journal.

This is an open-access article distributed under the terms and conditions of the Creative Commons Attribution license (http://creativecommons.org/licenses/by/3.0/). 